\title{
LANGUAGE PATTERN AND CONTENT VARIATION IN PRIVATE HINDI RADIO FMS: A STUDY
}

\author{
Pankaj Garg \\ Chitkara School of Mass Communication \\ Chitkara University, Punjab, India \\ Ashutosh Mishra \\ Chitkara School of Mass Communication \\ Chitkara University, Punjab, India
}

\begin{abstract}
At time when private FM radio stations are switching over to alternate patterns of language, it becomes imperative for academia to decipher what are the patterns and how much potential they have in keeping audience involved. The paper is based on the language used by radio presenter in contemporary time and that the success of messages is not altogether dependent of a standard and established language which has been practiced earlier generation of radio presenter. Alternate language patterns use nowadays in radio sometimes leave deep impression on listeners and society in general. In view of these facts, the present study attempts to understand the alternate language pattern of private FM radio stations in India and that too in Hindi centric belt. In this study, three different private radio stations have been taken for the study and one programme of each station has been analyzed in detail. These three radio stations are from New Delhi, Chandigarh, and Karnal. The study draws attention of the academia and radio industry on context to perception that despite popular standard style of presentation and language, there are presenters who are breaking the monotony of standard language and it's rules and are more concern with whether the audience will be able to extract meaning and comprehend it or not. The study explores possibilities of further study to analyze correlation between decoding of the messages by the listeners and their impact on public communication and its further impact on culture as well.
\end{abstract}

Keywords: Private FM, Radio Station, Language Pattern, Code-Mixing, Radio Jockey, Programme Content.

\section{INTODUCTION}

Unprecedented evolution and growth were witnessed in the history of mankind when human became conscious enough to decode their surroundings. Decoding of the surrounding by men didn't start with the advent of language only. It had started with the use of sign \& symbols and became a conveyor among early humans. Since the communication is basically meaning making process and a message can create meaning even in sign and symbol and some time silence carries some message; we need to understand the alternate mode of communication. But, it depends on the fact to what extent the sign and symbol or code language is popular among the community. And after the advent of the language as medium of communication, a large number of languages came into being throughout the world.

In the development process various cultures came together resulting into cross culture integration mixed use of the languages from opposite culture. A survey of European commission (2006) states that, 56 respondents were speaking a language other than their mother tongue e.g., 99 percent people of Luxembourg and 95 of Latvians speak more than one language.

The paper proceeds with argument that, cross culture integration made the mixed use of language a way of life and that needs to be studied in the prism of code switching e.g., using mixture of words of two or more languages while completing a sentence. The scholars (Marian, Shook, 2012) opined that majority of the world's population is bilingual or multilingual. They concluded that, bilingual brain has better attention and task switching capacity.

This study looks into the correlations of bilingual culture and use of code switching in media. It further analyzed to what extent media users are receptive to this trend. This study proceeds with the idea that, alternate 
language pattern adopted by private FM radio stations need serious research. It further argues that, private FM radio stations appears to be breaking rules by adopting their own code-mixing type language, but they are becoming a part of the community. At this point it is pertinent to mention the scholarly argument. According to Al Zabibi and Saleh (2017), when it becomes common practice to switch code e.g., a form of communication wherein speakers switch from one language to other in the same sentence, it becomes cultural feature and speech of the community is characterized by it. Some other scholars (Patel and Parikh, 2020) argued that, sentences with phrases from multiple languages are accepted among the various cultures.

In view of the above theorization by scholars from different disciplines, the paper is an attempt to decipher the meaning making potential of the communication with mixture of code (words) from different languages. To further elaborate the concept, the paper first of all defines the various dimensions of term code mixing/code switching. A 'code' is generally used in place of speech variety, language or dialect. Code-mixing or codeswitching means when a speaker mixes two or more languages in his/her communication. According to the definition in the Longman Dictionary, "A person may start speaking one language and then change to another one in the middle of their speech, or sometimes even in the middle of a sentence. On the other hand, code mixing is a mixing of two codes or languages, usually without a change of topic." Additionally, "Code mixing involves the assimilation of linguistic elements from one language into another: a sentence begins in one language then makes use of word(s) and grammatical features belonging to another and comes back to the first code." (Chowdhury, 2012). Multilingualism is a normal phenomenon in a country like India, where diverse culture, caste and languages co-exist. People frequently combined words from one language to another which result is codemixing. In present scenario, this code-mixing is also a key feature of the RJs to entertain and increase the listenership. They use different languages with various styles to attract and engage the listeners. The paper analyzed this pattern on the basis of various types of Code Mixing/Switching.
Intra- sentential code- mixing: in this type, mixing occurs within a sentence or a clause. In intra-sentential code-mixing, while speaking a sentence in one language speaker mixes the words from another language.

Inter (Extra)-sentential code-mixing: switching/mixing happens outside the sentence or the clause level. Speaker mixes the whole sentence or clause with one language to another.

Intra-word switching: this switching takes place within a word itself, like English 'movie' with Hindi plural turns into 'movieyaa'. (Ahmed and Tinny 2013: Tashi and Karekatti, 2019).The primary focus of this paper is to discuss the language pattern and content of the programmes broadcasted by private radio stations.

\section{Theoretical perspective of the research}

The research draws its theoretical basis from the 'structural' and 'social linguistic approach' of code switching (CS). The structural approach to CS (Boztepe, 2003) is concerned with formation of a sentence in any communication. This branch of study analyzes how a particular way of sentence formation in oral or written communication affects the encoding and decoding. On the other 'Social Linguistic' approach focuses on the aspect, how social meaning is created through CS. It is pertinent to mention here that these two areas underline a number of research problem related to the CS. In view of its importance in this branch of knowledge, the paper deconstructs the sentence formation (using CS) of some selected private radio stations on standard parameters that helps academia to know its meaning making potential. Along with this dimension, it analyses the social linguistic dimension from audiences' point of view e.g., to what extent they are at ease with CS in radio jockeys conversation. It also tests the conclusion of the scholars in the similar field who states that CS based communication reduce the linguistic distance and helpful to amplify the message and clarify what is said (Mahata et.al. 2020).

In time immemorial, the radio presenter used vocabulary which was not colloquial and hence was not used by a layman or common listeners. Listeners get impressed by the extreme formal language and style of the 
presenter. But times have changed; now radio jockey presents their programmes in such a language which we use and hear in our day to day lives. They likewise use the age specific language in their programmes. The purpose of this is it to connect with their listeners one to one. Listeners also feel now that the RJ is one of them.

Today, Radio jockey has the freedom to choose the way in which he wants to present the programme. (Ravi, 2012: Kak, 2008)

This study is based on to find out the language pattern and programme's content of the various private radio stations. The objective of the programming strategy is to fetch new listeners as well as retrain older listeners. Good listenership base can only be created by very good programming, content, music selection; RJs consist of good performance and connectivity with the audience. It is found that the various studies and researches have done on different private radio stations of various States \& cities, but no specific study has taken place on private radio stations operating in Hindi belt cities with reference to the language pattern and content strategy. In this context, this study focused on the analysis of private radios with special reference to their language pattern and content variation.

\section{Programming Format of Private FM Radio Channels}

Media allude to aggregate specialized apparatus that is utilized to convey the data to the huge mass at once; it incorporates print media, electronic media and new media. Lifestyle is the medium to express our life and the content about lifestyle is exceptionally spread by the media (Paul and Uikey, 2017). Similarly, language is also an essential part of the lifestyle, which could be described as one of the significant types of conversation that executes an essential place in human communication. To understand the language of the programmes broadcasted by private FM radio stations, we need to understand the programming format of them. Private FM radio channels are very different from All India Radio and Community Radio in terms of content, language and presentation. Private FM radio stations' style is fast, catchy, friendly and interactive. RJs have to represent a lot with few words because they have limited time to speak on-air. (Spangardt et.al. 2016:
Sen, 2014). The paper argues that these radio stations are targeting young listeners and designed the programme's format according to them. According to the scholars Sachdeva and Tripathi (2019), the young generation is the most important section of the society and also the most powerful for bringing a social change. The size of the youthful people's populace decides the development and potential of the nation. Youth is the most significant mass with enthusiasm, motivations and persistence for endorsing financial, social and cultural developments of a country.

\section{LITERATURE REVIEW}

Researcher reviewed the various research papers, books and articles to study the codemixing/switching language strategy of the Radio Jockeys and the programming content of the various radio stations running in India and internationally.To examine the language pattern of the radio presenters and programme's content of the radio stations, Okumbe M.A. (2017) has done a study on the three local radio stations of Kenya with the help of social responsibility theory. Researcher opined that, these radio stations have broken the monotony of English and Kiswahili languages and communicated programmes in nearby dialects. Listeners' contribution through phone-in based programmes is also enhancing this culture in the society. The researcher suggested that, the further study can be done on the reflection of the content upon the listeners, because radio stations are also responsible and accountable for the social development of the society.

The success of the FM radio channels has brought an exclusive change in speech style among the Bangladeshi youth. Ahmed S. and Tinny F. Z. (2013) studied this new phenomenon of the speech style using by the RJs and the listeners. The study pointed out the significant feature that, the RJs are using inter and intra-sentential code mixing/switching by mixing the language of Hindi, English and Bangla. The reason is that, RJs are being influenced by the new language pattern of the young generation to some extent. They adopted this mix language pattern so that their listeners could feel connected with them. Further, this study argues that with the adoption of this phenomenon of language, the young 
generation is creating a subculture among themselves.

Vijayakumar N. (2014) came up with an evaluative study about the listening pattern of FM radio users according to the language and content of the programmes in Mysore district. Descriptive statistics were used to analyze the collected data. The study mentions that, the younger generation is more inclined towards private radio stations and preferred to listen to it more frequently. While the old/aged audience still finds charm in listening to Vivid Bharati station, probably because of their old connection to its programmes since their young age and they do not identify themselves with the content and language of the private/commercial FM radio channels. FM radio stations can influence to its listeners in worldwide areas, so researcher recommended that, FM radio stations may work on redesigning the programming format and convert into an overall family entertainment medium so that its reach can also be enhanced.

In a study conducted by Dey A. and Pascale F. (2014) throws light on the fact that the most regular types of code-

switchingisintra-sententialand inter-sentential, which are being used in the communication. They investigated the rules and constraints of code-switching in Hindi-English mixed language data and explained the various reasons for the same. The majority of the Hindi speakers generally tend to turn toEnglish, because it is simpler to use the code -switching with

EnglishwordcomparedtoHindicounterpart.The othermostpopularreasonfor switching to Engli sh is to define the explanations, as it is someti mes simpler to understand the notion in Englis $\mathrm{h}$ than in Hindi and also whenever there is no well-known Hindi word for an English word. The study also pointed out that code switching occurs unintentionally as it has become a part of the speaking habit.

With this view, the language contact is an important phenomenon in the society, Barnali C. (2017) done an empirical study on the codemixing/switching and found that it has changed the meaning of communication in India. In terms of radio, the researcher found that, radio jockey purposely blend English words with Hindi sentences to sound more funky and trendy. The researcher recommended that, this code mixing \& switching trend have set up themselves as the most widely used language in the Hindi speaking states. In a multilingual country like India code-mixing and switching has become a norm rather than a deviation.

To examine the code mixing language pattern of the public and private radio stations in the Kohlapur city of Maharashtra, Tashi K. And Karekatti T. (2019)analyzed the recorded data of the radio stations. On the basis of the talking data of the RJs, it is found that,codemixing takes place more in the programmes broadcasted by Radio Mirchi \& Tomato FM and much less on Prasarbharati channel. Researcher opined that, wheneverjockeysorannouncers are unable to $r$ ecollect a suitablewordinMarathilanguage, the y combine Englishwords as common people do in their daily conversation.

In the view of the study of the related literature, content analysis methodology has applied in this paper to accomplish the desired result.

\section{OBJECTIVES OF THE STUDY}

- To analyze the usage of differentlanguages by private radio stations located at various places.

- To study the variety of content of programmes broadcasted by private radio stations.

- To understand the social linguistic approach in code-mixing/switching used by private FM radio stations.

\section{RESEARCH METHODOLOGY}

In this study, for analyzing the selected radio stations' content, the researcher conducted qualitative research and applied content analysis technique for describing the data. Content Analysis is described as the scientific study of the content of communication. Kerlinger (1986) defined content analysis as a method of studying and analyzing communication in a systematic, objective and quantitative manner for the purpose of measuring variables. According to Weber (1985), content analysis is a research methodology that utilizes a set of procedures to make valid inferences from text. These inferences are about the sender(s) of the message, the message itself, or the audience of message. In this study, the data of three 
private radio stations were selected and analyzed on various parameters. These radio stations are from 3 different areas such as Ishq FM from New Delhi, Big FM from Chandigarh and Radio City from Karnal.

One week programme of the each radio station is the sample size for the content analysis. From morning time band show Ishq FM of New Delhi and Radio City of Karnal was taken. In the evening time band show, Big FM of Chandigarh was in the sample.

The researcher selected the morning and evening time band shows for the study because both time band shows are considered as drive time shows and has a highest listenership. In this research, content analysis technique has applied for analyzing many recorded words and sentences into different content categories based on explicit rule of coding. First of all, the researcher recorded the selected aired contentmeans radio showsand then it was analyzed. Self-observations were also conducted in order to support the significance of the result.

DATA ANALYSIS

The researcher listened to the recorded audio
Table-2-Data of Code mixing by RJs

\begin{tabular}{|c|c|c|c|c|c|}
\hline $\begin{array}{c}\text { Sr. } \\
\text { No. }\end{array}$ & $\begin{array}{c}\text { Radio } \\
\text { Station }\end{array}$ & $\begin{array}{c}\text { RJ } \\
\text { Name }\end{array}$ & $\begin{array}{c}\text { Intra } \\
\text { Sententialcode- } \\
\text { mixing }\end{array}$ & $\begin{array}{c}\text { Inter } \\
\text { Sentential } \\
\text { code- } \\
\text { mixing }\end{array}$ & $\begin{array}{c}\text { Intra- } \\
\text { Word } \\
\text { Switching }\end{array}$ \\
\hline 1 & Big FM & $\begin{array}{c}\text { Vidya } \\
\text { Balan }\end{array}$ & 265 Words & $\begin{array}{c}10 \\
\text { Sentences }\end{array}$ & 0 \\
\hline 2 & $\begin{array}{c}\text { Ishq } \\
\text { FM }\end{array}$ & Sarthak & 105 Words & $\begin{array}{c}130 \\
\text { Sentences }\end{array}$ & 0 \\
\hline 3 & $\begin{array}{c}\text { Radio } \\
\text { City }\end{array}$ & Rocky & 190 Words & $\begin{array}{c}8 \\
\text { Sentences }\end{array}$ & 4 \\
\hline
\end{tabular}

Source:'Authors' Calculations'

This table provides the data of using codemixing by RJs of these 3 radio stations. The maximum Intra sentential code-mixing is done by the RJ of BIG FM. However, Radio City is at number two by using 190 words in one week under intra sentential code-mixing category and then followed by Ishq FM comprises 105 words in a week for the same category. Thereafter, in inter sentential code-mixing type; RJ of Ishq FM has done code-mixing in 130 sentences, whereas, RJ of BIG FM just limited herself on 10 sentences, which are a huge difference. In fact, RJ of Radio City has used only 8 sentences in his show. One more category called intra word switching is being used by RJ of Radio City only.

Table-2.1- Examples of Intra Sentential Code Mixing by RJ Vidya Balan on BIG FM

Table-1-Details of the selected radio stations and content's duration

\begin{tabular}{|c|c|c|c|c|c|c|}
\hline $\begin{array}{c}\text { Radio } \\
\text { Station }\end{array}$ & Show Timing & RJ Name & Show Name & Place & $\begin{array}{c}\text { Total duration of } \\
\text { recorded content }\end{array}$ & $\begin{array}{c}\text { Total duration of } \\
\text { RJ's Content }\end{array}$ \\
\hline Ishq FM & $7 \mathrm{am}-11 \mathrm{am}$ & Sarthak & Ishq & Delhi & 20 Hours & 198.25 Minutes \\
\hline Big FM & $7 \mathrm{pm}-9 \mathrm{pm}$ & $\begin{array}{c}\text { Vidya } \\
\text { Balan }\end{array}$ & $\begin{array}{c}\text { Dhun badal ke toh } \\
\text { dekho }\end{array}$ & $\begin{array}{c}\text { Chandigarh } \\
\text { (also } \\
\text { broadcasted in } \\
\text { all stations of } \\
\text { BIG FM) }\end{array}$ & 10 Hours & 74.13 Minutes \\
\hline Radio City & $7 \mathrm{am}-11 \mathrm{am}$ & Rocky & 7 se 11 & Karnal & 20 Hours & 114.09 Minutes \\
\hline
\end{tabular}

\section{Source:Authors' Calculations'}

files in the Sound Forge software and identified the RJs' and callers/guests' talking content so that the 'links' can be analyzed in depth. In this section, the Hindi words and sentences are marked in italic font.

This table evident that, tentative a total of 50 hours of aired radio shows/programmes' content were recorded from three radio stations. A total of 6 hours, 43 minutes and 47 seconds of content of RJs' links was identified, which was analyzed on various parameters. One syndicate show of Big FM is also included in the study, which was broadcasted in many stations simultaneously.

\begin{tabular}{|c|l|l|}
\hline $\begin{array}{c}\text { Sr. } \\
\text { No. }\end{array}$ & $\begin{array}{l}\text { On-Air Content of RJ } \\
\text { Vidya Balan }\end{array}$ & $\begin{array}{c}\text { Code Mixing } \\
\text { Structure } \\
\text { (Mixing of } \\
\text { English words } \\
\text { in Hindi } \\
\text { language) }\end{array}$ \\
\hline 1 & $\begin{array}{l}\text { Aisa karna kisi ke self } \\
\text { confidence ko kitni } \\
\text { thes pahuncha sakta hai }\end{array}$ & Self confidence \\
\hline 2 & $\begin{array}{l}\text { Bure percentage se } \\
\text { duniya khatam nahi ho } \\
\text { jaati aur na hi ache } \\
\text { marks decide kerte hai } \\
\text { ki aage jaa ke bache apni } \\
\text { life se kaise deal }\end{array}$ & $\begin{array}{l}\text { Percentage, } \\
\text { Decide, } \\
\text { Deal, }\end{array}$ \\
\hline
\end{tabular}




\begin{tabular}{|l|l|l|}
\hline 3 & karenge & \\
\hline 3 & kisi ke rang, size ya & Comments, \\
shape ko lekar us par & Humiliate \\
& $\begin{array}{l}\text { comments karna ya } \\
\text { mazak uda ker unhe } \\
\text { humiliate karna body } \\
\text { shaming kehlaata hai }\end{array}$ & \\
\hline 4 & $\begin{array}{l}\text { Feature ke liye } \\
\text { constantly toka jaaye }\end{array}$ & Constantly, \\
& $\begin{array}{l}\text { ya mazak banaya jaaye } \\
\text { toh inadequate ya }\end{array}$ & Under \\
& $\begin{array}{l}\text { confident, } \\
\text { karna natural hai }\end{array}$ & Natural \\
\hline 5 & $\begin{array}{l}\text { Bachpan umar ka wo } \\
\text { hissa jo sebse zyada } \\
\text { care free aur exciting } \\
\text { maana jaata tha ab wahi } \\
\text { sabse bade stress ka } \\
\text { reason hai }\end{array}$ & Care free, \\
\hline
\end{tabular}

Source:Authors' Calculations'

Table-2.2- Examples of Inter Sentential Code Mixing by RJ Vidya Balan on BIG FM

\begin{tabular}{|c|l|}
\hline $\begin{array}{c}\text { Sr. } \\
\text { No. }\end{array}$ & \multicolumn{1}{|c|}{ On-Air Content of RJ Vidya Balan } \\
\hline 1 & $\begin{array}{l}\text { Saare hi parents apne bacho ko successful } \\
\text { dekhna chahte hai. which is ok. }\end{array}$ \\
\hline 2 & $\begin{array}{l}\text { I do feel ki haan hamari society badal rahi } \\
\text { hai. }\end{array}$ \\
\hline 3 & $\begin{array}{l}\text { Unhe in naamo se address kerna bilkulbhi } \\
\text { funny nahi hai. Body shaming is not a } \\
\text { joke. }\end{array}$ \\
\hline 4 & $\begin{array}{l}\text { Neha, I can totally relate to you kyunki } \\
\text { maine bhi kaafi kuch aapki tarah face kiya } \\
\text { hai. }\end{array}$ \\
\hline 5 & $\begin{array}{l}\text { Mere saath hai Mohit. Mohit what do you } \\
\text { think }\end{array}$ \\
\hline
\end{tabular}

Source:'Authors' Calculations'

In the above mentioned examples, RJ Vidya used the complete sentences in one language and then moved to another language.

Table-2.3- Examples of Intra Sentential Code Mixing by RJ Sarthak on Fever FM

\begin{tabular}{|c|l|l|}
\hline $\begin{array}{l}\text { Sr. } \\
\text { No. }\end{array}$ & $\begin{array}{c}\text { On-Air Content of } \\
\text { RJ Sarthak }\end{array}$ & $\begin{array}{c}\text { Code Mixing } \\
\text { Structure } \\
\text { (Mixing of } \\
\text { English words in } \\
\text { Hindi language) }\end{array}$ \\
\hline 1 & $\begin{array}{l}\text { kya imperial music } \\
\text { bajaya hai aur ye } \\
\text { pure water aur ye } \\
\text { green tea ki health }\end{array}$ & $\begin{array}{l}\text { Imperial, } \\
\text { Pure water, } \\
\text { Green tea }\end{array}$ \\
\hline 2 & Tuesday morning & Tuesday morning \\
\hline
\end{tabular}

\begin{tabular}{|c|l|l|}
\hline & aa chuki hai & \\
\hline 3 & $\begin{array}{l}\text { Matlab intellectual } \\
\text { satisfaction ke saath } \\
\text { materialistic joy ohh } \\
\text { yaar }\end{array}$ & $\begin{array}{l}\text { Intellectual } \\
\text { satisfaction, } \\
\text { Materialistic joy }\end{array}$ \\
\hline 4 & $\begin{array}{l}\text { Beating me in the } \\
\text { music matlab ye toh } \\
\text { ekdum salt in the } \\
\text { wounds wala scene } \\
\text { ho gaya }\end{array}$ & $\begin{array}{l}\text { Beating me in the } \\
\text { Susic, in the } \\
\text { wounds, } \\
\text { Scene }\end{array}$ \\
\hline 5 & $\begin{array}{l}\text { Saat samunder paar } \\
\text { se queen ki } \\
\text { blessings ke saath } \\
\text { aayi tea hai. }\end{array}$ & Queen, \\
Teasings, \\
\hline
\end{tabular}

Source:Authors' Calculations'

Table-2.4- Examples of Inter Sentential Code Mixing by RJ Sarthak on Fever FM

\begin{tabular}{|c|l|}
\hline $\begin{array}{c}\text { Sr. } \\
\text { No. }\end{array}$ & \multicolumn{1}{|c|}{ On-Air Content of RJ Sarthak } \\
\hline 1 & $\begin{array}{l}\text { Then will call you back aur thode se } \\
\text { sawalo ka jawab dijiye and who knows } \\
\text { you could be the one for flying with } \\
\text { your significant one for ishq in England. }\end{array}$ \\
\hline 2 & $\begin{array}{l}\text { Ashish 2 sahi jawab to de diye hai lady ne } \\
\text { haar toh tum chuke ho matlab play for } \\
\text { pride old champ. }\end{array}$ \\
\hline 3 & $\begin{array}{l}\text { You are sounding so happy yaar matlab } \\
\text { aise lag raha hai ki Monday morning toh } \\
\text { hai hi nahi bilkul ekdum. }\end{array}$ \\
\hline 4 & $\begin{array}{l}\text { Monday morning kisi chal rahi hai } \\
\text { tumhari. you are a manager with telecom } \\
\text { firms. }\end{array}$ \\
\hline 5 & $\begin{array}{l}\text { You are of course an assistant general } \\
\text { manager with a consumer electronic } \\
\text { sponsors aur subah subah aapko lga ki thodi } \\
\text { chai pee leni chaiye radio pe. }\end{array}$ \\
\hline
\end{tabular}

Source:'Authors' Calculations'

In the above examples, RJ Sarthak used the complete sentence in one language and then switched to another language.

Table-2.5- Examples of Intra Sentential Code Mixing by RJ Rocky on Radio City

\begin{tabular}{|c|l|l|}
\hline $\begin{array}{l}\text { Sr. } \\
\text { No. }\end{array}$ & $\begin{array}{l}\text { Content of RJ } \\
\text { Rocky }\end{array}$ & $\begin{array}{l}\text { Code Mixing } \\
\text { Structure } \\
\text { (Mixing of } \\
\text { English words in } \\
\text { Hindi language) }\end{array}$ \\
\hline 1 & $\begin{array}{l}\text { Main is baat pe two } \\
\text { hundred percent } \\
\text { believe karta hu }\end{array}$ & $\begin{array}{l}\text { Two hundred } \\
\text { percent believe }\end{array}$ \\
\hline 2 & $\begin{array}{l}300 \text { plus runs } \\
\text { impossible sa hi } h i\end{array}$ & $\begin{array}{l}\text { Plus, } \\
\text { impossible }\end{array}$ \\
\hline
\end{tabular}




\begin{tabular}{|c|l|l|}
\hline & kaam hai & \\
\hline 3 & $\begin{array}{l}\text { Friday wali good } \\
\text { morning }\end{array}$ & Friday \\
\hline 4 & Multi story bhawan & Multi story \\
\hline 5 & $\begin{array}{l}\text { Ye difference hi sab } \\
\text { kuch create karta hai }\end{array}$ & $\begin{array}{l}\text { Difference, } \\
\text { Create }\end{array}$ \\
\hline
\end{tabular}

Source:Authors' Calculations'

Table-2.6- Examples of Inter Sentential Code Mixing by RJ Rocky on Radio City

\begin{tabular}{|c|l|}
\hline $\begin{array}{c}\text { r. } \\
\text { No. }\end{array}$ & \multicolumn{1}{|c|}{ On-Air Content of RJ Rocky } \\
\hline 1 & $\begin{array}{l}\text { Kamaal ke batsman kamal ke bowler. He is } \\
\text { an amazing bowler. }\end{array}$ \\
\hline 2 & $\begin{array}{l}\text { Mind blowing acting and mind blowing } \\
\text { movie and anamika banti hai hamari aaj } \\
\text { ki lucky winner. }\end{array}$ \\
\hline 3 & Let's see kya hota hai. \\
\hline
\end{tabular}

Source:Authors' Calculations'

In the above mentioned examples, RJ Rocky used the Hindi and English languages in both the sentences.

Table-2.7- Examples of Intra-word switching by RJ Rocky on Radio City

\begin{tabular}{|c|c|}
\hline $\begin{array}{c}\text { Sr. } \\
\text { No. }\end{array}$ & On-Air Content of RJ Rocky \\
\hline 1 & Movieya (Movies) \\
\hline 2 & Coaching centro (Centres) \\
\hline 3 & Schooli (Schools) \\
\hline 4 & Liney (lines) \\
\hline
\end{tabular}

Source:Authors' Calculations'

In the above mentioned examples, intra word code-switching occurred within these words itself here English word turned into Hindi plural.

Table-3-Data of Code mixing by Callers/Guest

\begin{tabular}{|c|c|c|c|c|}
\hline $\begin{array}{c}\text { Sr. } \\
\text { No } \\
\cdot\end{array}$ & $\begin{array}{c}\text { Radio } \\
\text { Statio } \\
\mathbf{n}\end{array}$ & $\begin{array}{c}\text { Intra } \\
\text { Sententialcod } \\
\text { e-mixing }\end{array}$ & $\begin{array}{c}\text { Inter } \\
\text { Sententia } \\
\text { 1 code- } \\
\text { mixing }\end{array}$ & $\begin{array}{c}\text { Intra- } \\
\text { Word } \\
\text { Switchin } \\
\mathbf{g}\end{array}$ \\
\hline 1 & $\begin{array}{c}\text { Big } \\
\text { FM }\end{array}$ & 85 Words & 60 & 0 \\
\hline 2 & $\begin{array}{c}\text { Ishq } \\
\text { FM }\end{array}$ & 30 Words & $\begin{array}{c}65 \\
\text { Sentences }\end{array}$ & 0 \\
\hline 3 & $\begin{array}{c}\text { Radio } \\
\text { City }\end{array}$ & 25 Words & $\begin{array}{c}10 \\
\text { Sentences }\end{array}$ & 0 \\
\hline
\end{tabular}

Source:Authors' Calculations'

This table evident the data of using codemixing by listeners/callers on the conversation with the RJs through phone of these 3 radio stations. The most extreme code-mixing is done by the callers/guest of BIG FM with 85 words in one week in Intra sentential codemixing category. However, Ishq FM is on the second position by utilizing 30 words in a single week and afterward pursued by Radio City contains 25 words in a single week for a similar classification. From there on, in inter sentential code-mixing type, callers/guest on Ishq FM used code-mixing in 65 sentences though callers/guest of BIG FM used 60 sentences. Callers/guest of Radio City simply constrained themselves on 10 sentences which is an enormous contrast. Intra word switching is not utilized by any caller.

Table-3.1- Examples of Intra Sentential Code Mixing by Callers/Guests on BIG FM

\begin{tabular}{|c|l|l|}
\hline $\begin{array}{l}\text { Sr. } \\
\text { No. }\end{array}$ & \multicolumn{1}{|c|}{$\begin{array}{c}\text { On-Air Content of } \\
\text { Callers/Guest }\end{array}$} & $\begin{array}{c}\text { Code Mixing } \\
\text { Structure } \\
\text { (Mixing of } \\
\text { English words } \\
\text { in Hindi } \\
\text { language) }\end{array}$ \\
\hline 1 & $\begin{array}{l}\text { I think bachpan se hai } \\
\text { aise incidents ko main } \\
\text { yaad ker ker ke hi } \\
\text { strong hui hu. }\end{array}$ & $\begin{array}{l}\text { Ithink, } \\
\text { Incidents, } \\
\text { Strong }\end{array}$ \\
\hline 2 & $\begin{array}{l}\text { Bacpan mein definitely } \\
\text { padta tha because itni } \\
\text { strength nahi thi. }\end{array}$ & $\begin{array}{l}\text { Definitely } \\
\text { Because } \\
\text { Strength }\end{array}$ \\
\hline 3 & $\begin{array}{l}\text { Comparison ke } \\
\text { chakkar mein humare } \\
\text { jo ambitious hai wo } \\
\text { kahin na kahin bacho } \\
\text { ke upar impose ker } \\
\text { rahe hai. }\end{array}$ & $\begin{array}{l}\text { Comparison, } \\
\text { Ampitious, }\end{array}$ \\
\hline
\end{tabular}

Source:Authors' Calculations'

Table-3.2- Examples of Inter Sentential Code Mixing by Callers/Guests on BIG FM

\begin{tabular}{|c|l|}
\hline $\begin{array}{c}\text { Sr. } \\
\text { No. }\end{array}$ & \multicolumn{1}{|c|}{ On-Air Content of Callers/Guests } \\
\hline 1 & $\begin{array}{l}\text { Pichle ek saal mein pregrancy ki wajah se mera } \\
\text { 20-25 kilo wazan bada tha. Logo ne iske liye } \\
\text { mujhe tokka bhi hai. But I love myself the way } \\
\text { I am because I have the most beautiful } \\
\text { reason to be fat that is my son. }\end{array}$ \\
\hline 2 & $\begin{array}{l}\text { Toh har cheez ko pressure le le ker karna I think } \\
\text { that is why we hear so much of people } \\
\text { passes away at such young age. }\end{array}$ \\
\hline 3 & $\begin{array}{l}\text { So I don't want negativity around me. jitna } \\
\text { avoid ker sakti hu kerti hu. }\end{array}$ \\
\hline
\end{tabular}

Source:Authors' Calculations' 
In the above mentioned examples, callers/guests used the Hindi and English languages in their conversation with the RJ.

\begin{tabular}{|c|l|l|}
\hline $\begin{array}{c}\text { Table-3.3- } \\
\text { Examples } \\
\text { of Intra } \\
\text { Sentential } \\
\text { Code } \\
\text { Mixing } \\
\text { by } \\
\text { Callers/ } \\
\text { Guests on } \\
\text { Ishq } \\
\text { FMSr. } \\
\text { No. }\end{array}$ & $\begin{array}{c}\text { On-Air Content of } \\
\text { Callers/Guests }\end{array}$ & $\begin{array}{c}\text { Code Mixing } \\
\text { Structure } \\
\text { (Mixing of } \\
\text { English words } \\
\text { in Hindi } \\
\text { language) }\end{array}$ \\
\hline 1 & $\begin{array}{l}\text { Grass ke saath thoda } \\
\text { mitti bhi aayega }\end{array}$ & Grass \\
\hline 2 & $\begin{array}{l}\text { Flower ke jaisa logo } \\
\text { hota hai }\end{array}$ & Flower \\
\hline 3 & $\begin{array}{l}\text { Haan agar mera } \\
\text { network nahi aa raha } \\
\text { hai because of you }\end{array}$ & Because of \\
\hline
\end{tabular}

Source:Authors' Calculations'

Table-3.4- Examples of Inter Sentential Code Mixing by Callers/Guests on Ishq FM

\begin{tabular}{|c|l|}
\hline $\begin{array}{c}\text { Sr. } \\
\text { No. }\end{array}$ & \multicolumn{1}{|c|}{ On-Air Content of Callers/Guests } \\
\hline 1 & $\begin{array}{l}\text { Jab aap camera chalate ho every time you turn } \\
\text { it on and goes back to default mode. }\end{array}$ \\
\hline 2 & $\begin{array}{l}\text { you know, what I like about you. Ghamand } \\
\text { nahi hai yaar tum mein }\end{array}$ \\
\hline 3 & $\begin{array}{l}\text { Now the problem with first two types of } \\
\text { people is ki unki zindagi mein ek ajeeb si } \\
\text { vidambna hai. }\end{array}$ \\
\hline
\end{tabular}

\section{Source:Authors' Calculations'}

In the above mentioned examples, callers/guests started speaking in one language and then switched to another language.

Table-3.5- Examples of Intra Sentential Code Mixing by Callers/Guest on Radio City

\begin{tabular}{|c|l|l|}
\hline $\begin{array}{l}\text { Sr. } \\
\text { No. }\end{array}$ & \multicolumn{1}{|c|}{$\begin{array}{c}\text { On-Air Content of } \\
\text { Callers/Guest }\end{array}$} & $\begin{array}{c}\text { Code Mixing } \\
\text { Structure } \\
\text { (Mixing of } \\
\text { English words } \\
\text { in Hindi } \\
\text { language) }\end{array}$ \\
\hline 1 & $\begin{array}{l}\text { Isme thoda na leniency } \\
\text { ki wajah se ho raha hai. }\end{array}$ & leniency \\
\hline 2 & $\begin{array}{l}\text { Ye unbelievable team } \\
\text { hai }\end{array}$ & Unbelievable \\
\hline 3 & $\begin{array}{l}\text { Infect 5 baar inke saath } \\
\text { aisa hua hai }\end{array}$ & Infect \\
\hline
\end{tabular}

Source:Authors' Calculations'
Table-3.6- Examples of Inter Sentential Code Mixing by Callers/Guest on Radio City

\begin{tabular}{|c|l|}
\hline $\begin{array}{c}\text { Sr. } \\
\text { No. }\end{array}$ & \multicolumn{1}{|c|}{ Callers/Guests } \\
\hline 1 & $\begin{array}{l}\text { Aur mazedaar baat kya hai haar baar all } 5 \\
\text { occasions they won the game. }\end{array}$ \\
\hline 2 & $\begin{array}{l}\text { Dil keh raha hai India dimaag keh raha hai } \\
\text { Australia. So dil over dimaag, dimaag over } \\
\text { dil. }\end{array}$ \\
\hline
\end{tabular}

Source:'Authors' Calculations'

In the above mentioned examples, callers/guests giving their viewpoint in both the languages.

\section{Finding and conclusion}

The study was conducted to identify the language pattern of the private $\mathrm{FM}$ radio stations and variation in the content of the programme. The study concludes that, RJs are presenting programmes in a language, which they feel is appropriate according to the topic and the target listeners. It is also observed that, RJs are utilizing full range and assortment of words and sentences of different languages in their presentation. Usage of Code mixing language pattern is a natural mode of speaking in private FM radio programmes. But it is also found that, this pattern is free from the standard norms and rules of the any particular language. Even listeners are also decoding this code mixing pattern and using it during the conversation with the RJs. By doing this, RJs and listeners are trying to create and maintain a strong association between them. The paper argues that, the primary objective of the usage of this code-mixing pattern is to express the particular topic, so that listeners can understand in a better way. Another objective is to attract and enhance the listenership of the radio station.

The study also reveals that, $\mathrm{RJs}$ of these radio stations are using this code-mixing/switching language pattern a lot in their communication, ether it is inter sentential code-mixing or intra sentential code-mixing. Different words from regional languages are also being used by the RJs. Several English words are so frequent in Hindi that they have become a part of Hindi language.

In terms of content, the study concludes that, commercial FM radio stations are providing the content variation in their programmes. The content and presentation of the every 
programme is entirely different from each other. Private FM radio stations have created programme names, segments and other station utilities based on such words and languages which are targeting the young listeners. The content of these programmes of Radio City, Big FM and Ishq FM is mainly based on the various segments related tosocial issues,current affairs and phone-in conversation. Bollowood actress Vidya Balan hosted the show 'Dhun Badal ke toh Dekho' on Big FM and picks up the issue pertaining to society and trending social problems and tries to come up with a solution of such issues. This show comprises various segments such as 'Reporter kaviraj' in which topic of the show used to be described in a poetic way by one poet. The show has another section in which viewpoints/opinions from famous bollywood celebrities and other listeners were also included. The show broadcasted by Ishq FM has two phone-in contests named 'Battle of sexes' and 'Youbet' in which listeners participated and got a chance to win the exciting prizes on-air.

RJ also describes brief description about any one word in the show as 'word of the day segment.' In the programme of Radio City, RJ conveyed the traffic update, city update and weather update to inform the listeners. The content of this show is based on the current happenings related to International, National, Regional and local. RJ also included one phone-in contest, which was related to films. A part of phone-in, RJ played the vox-pop bytes from common people based on the various social issues. RJs are communicating in casual style, formal style and consultative style according to the content and target listeners of their programmes.

\section{LIMITATION AND FURTHER SCOPE OF THE STUDY}

There are certain limitations in this study. The present study has been conducted only from the 3 private radio channels of 3 Hindi belt cities- New Delhi, Chandigarh and Karnal. Therefore, we are not sure whether these results could be generalized to the other part of the Hindi belt cities. Due to the time constraints, it was not possible to take 24 hours content of the each radio, so only one time band show of each radio station was analyzed. The other time band shows must have some other different content of the programme. Hence, the study further can be extended by taking other programmes of different private radio stations from other cities. Another area is that, to find out the more reasons of using code-mixing or code-switching for further research.

\section{REFERENCES}

Ahmed S. and Tinny F. Z. (2013) "The RJ style: brought to you by Bangladeshi FM radio", StamfordJournal of English, Vol.6, No.0, pp126.

Al Zabibi, Saleh A. (2017) "Translatability and the Message Imbedded in Code Switching", International Journal of Languages and Linguistics. Vol.4, No.2.

Barnali C. (2017) “Code-switching and mixing in communication-A study on language contact in Indian media", SSRN Electronic Journal.

Boztepe, E. (2003) "Issues in code-switching: Competing Theories and Models", Studies in Applied Linguistics and TESOL, Vol. 3, No.2.pp 1-27

Chowdhury S. (2012) "Code-mixing as a strategy used by radio jockey's on RadioMirchi 93.9 FM (Pune)", The Criterion An International Journal in English, Vol.3,No.4,pp $1-13$.

Dey A. and Pascale F. (2014) "A Hindi-English Code-Switching Corpus", International Conference on Language Resources and Evaluation.

Gratz T. (2014). Radio Call-In Shows on Intimate Issues in Benin: "Crossroads of

Sentiments", African Studies Review, Vol. 57, pp 25-48.

Kak A. (2008) "Essentials and practices of radio management", pp 141-154, Wings Institute of Broadcasting.

Kumari, A.(2011) "Media:The key driver of consumerism, macro-micro linkages andpolicy dimensions-a case study of FM Radio", History and Sociology of South Asia, Vol. 5, No. 1, pp1-30.

Mahata S.K., Makhija S., Agnihotri A., Das D. (2020), "Analyzing Code-Switching Rules for English-Hindi Code-Mixed Text", pp 137-145, In Emerging Technology in Modelling and Graphics. Springer, Singapore. 
Marian, V., and Shook, A. (2012). "The Cognitive Benefits of Being Bilingual", Cerebrum: the Dana Forum on Brain Science, 2012 Sep-Oct; 2012: 13.

Okumbe M.A., Peel C., Adagala N., Kowuor R. and Obonyo L. (2007) "An Assessment of the Kenyan Journalism Training and Gaps Filled by Other Professionals: A Study of Selected FM Radio Stations", International Journal of Communication, Vol.1, No.2, pp 121.

Paul S. and Uikey S. (2017),"Media and Lifestyle: A Study of Media influence on the Dressing Style",Journal of Content, Community \& Communication, Vol. 6, pp 5666.

Patel, D. and Parikh R. (2020) "Language Identification and Translation of English and Gujarati Code-Mixed Data", 2020 International Conference on Emerging Trends in Information Technology and Engineering (ic-ETITE). Vellore, India, 2020, pp. 1-4.

Prasad B. D. (2018), "Content Analysis. A Method in Social Science Research"

Ravi B.K. (2012) “Techno-lingual ambiguities of Indian media: A critical study",Academic Research International, Vol. 3, No. 2, pp 224230.
Sachdeva P. and Tripathi D. (2019)," A Critical Education for 21st Century: A study on Youth and Media literacy", Journal of Content, Community \& Communication, Vol. 10, pp 6472.

Tashi K. and Karekatti T. (2019) “Code Mixing on Prasarbharati and Private FM Channels: A Comparison", International Journal of English Language, Literature in Humanities,Vol. 7, No. 4, pp 527-542

Sen B. (2014), "A new kind of radio: FM broadcasting in India", Media, Culture \& Society, Vol.36, No.8, pp 1084-1099.

Spangardt B., Ruth N. and Schramm H. (2016). "... And please visit our face book page, too!" how radio presenter personalities influence listeners' interactions with radio stations, Journal of Radio \& Audio Media,Vol. 23, No.1, pp 68-94.

Vijayakumar N. (2014), “An evaluative study of healthy listening pattern among FM radio listeners: A special reference to Mysore district", International Academic Journal of Information Systems and Technology,Vol.1, No.1, pp 1-11.

\section{Private Radio Stations}

- Big FM

- Ishq FM

- Radio City 